\title{
Locally Advanced Melanoma
}

National Cancer Institute

\section{Source}

National Cancer Institute. Locally Advanced Melanoma. NCI Thesaurus. Code C148494.

Melanoma that has spread from its original site of growth to nearby tissues or lymph nodes. 